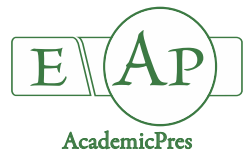

Available online: www.notulaebotanicae.ro

Print ISSN 0255-965X; Electronic 1842-4309

Not Bot Horti Agrobo, 2019, 47(2):478-486. DOI:10.15835/nbha47111378

Original Article

\title{
Identification of Soils Factors Influence in the Distributions of Tuber aestivum in Transylvanian Subcarpathian Hill, Romania
}

\section{Horea PĂCURAR ${ }^{1}$, Marcel DÎRJA $^{1}$, Mihai BUTA ${ }^{1}$, Ioan PĂCURAR ${ }^{1 *}$, Sanda ROȘCA ${ }^{2}$, Ștefan BILAȘCO ${ }^{2,3}$}

\author{
${ }^{1}$ University of Agricultural Sciences and Veterinary Medicine, 3-5 Manastur St., 400372 Cluj-Napoca, \\ Romania;pacurar_horea@yahoo.com;mdirja@usamvcluj.ro;mbuta@usamvcluj.ro;ioanpacurarcj@yahoo.com (correspondingauthor) \\ ${ }^{2}$ Babeș-Bolyai University, Faculty of Geography, Department of Physical and Technical Geography, \\ Clinicilor Street, 400006 Cluj-Napoca, Romania; sanda.rosca@ubbcluj.ro \\ ${ }^{3}$ Romanian Academy, Cluj-Napoca Subsidiary Geography Section, 9 Republicii Street, \\ 400015Cluj-Napoca, Romania; stefan.bilasco@ubbcluj.ro
}

\begin{abstract}
Truffles are one of the most hunted varieties of mushrooms in Europe due to their high price and their increasingly frequent use in the kitchen. As demonstrated by several studies, soil conditions are among the main factors that influence the spread and development of the black truffle species. The purpose of this study was to identify the soil factors which directly and indirectly influence the distribution of black truffles (Tuber aestivum Vittad.) in Romania and to identify the areas from the Subcarpathian Hills of Transylvania which are highly favourable to their existence and growth, using G.I.S. spatial analysis and databases which include soil characteristics (soil type, texture, gleization, stagno-gleization) and territorial localisation through GPS points indicating the samples of Tuber aestivum. By implementing the statistical model of spatial analysis (BSA Bivariate Statistical Analysis) for each characteristic, a series of areas were classified into three classes of favourability (low, medium, high) for the growth of Tuber aestivum. The results were validated indirectly by comparing the overlapping of the areas from the high favourability class with the areas covered with tree species from the Quercus genus and directly, through field research (on the surfaces with maximum favourability), done by specialised truffle seekers. The results were validated with a very high confidence rate for both methods (method 1 - overlapping of approximatively 93\%, method 2 - Tuber aestivum was identified on 12 out of 15 test surfaces from the high favourability class).
\end{abstract}

Keywords: G.I.S. modelling; soil characteristics; Tuber aestivum

\section{Introduction}

Truffles are one of the most hunted varieties of mushrooms worldwide due to their high price and their gastronomic importance (Harley and Smith, 1983; Pacioni and Pomponl, 1991; Milenković et al., 1992; Montechi and Sarasini, 2000; Csorbainé, 2001; Dam Sao et al., 2012; Garcia-Montero et al., 2014), the number of truffle seekers increasing continuously both in Europe and in Romania (Csorbaine, 2001; Streiblová et al., 2010; Zambonelli et al., 2012).

Specialised studies (Linderman 1988; Deveau et al., 2007; Streiblová et al., 2010; Gryndler and Hršelová, 2012; Benucci et al., 2012) mention among the factors which influence the spread and the growth of the black truffle species mostly the soil conditions and some particular animal species (Zoltán et al., 2009) with direct and indirect influence on soils, especially protozoans and worms, as well as earthworms or some insects whose influence can be identified up to 15 centimetres inside the soil. They air the soil and increase its fertility by participating directly in the decay of organic matter, while earthworms can increase the soil permeability through the small tunnels they create, their presence being even an indirect indicator of truffle presence (the soil acidity preferred by earthworms is similar to the $\mathrm{pH}$ interval of 5.5-8.5 which is suitable for truffles) (Racolța, 2015).

$T$. aestivum grows in symbiosis with tree species from the genera Castanea, Cistus, Corylus, Fagus, Ostrya, Tilia, Picea, Carya, Pinus and Quercus (Wang et al., 2008; Chevalier, 2009; Wedén et al., 2009; Benucci et al., 2012; 
Stobbe et al., 2013), approximately 30 tree species being identified in Europe (Ceruti et al., 2003). In order for the sol to fulfil the requirements for truffle growth, an ideal content of macro elements is necessary, like phosphorus (as mineral phosphates), nitrogen (resulted from water, air and microorganisms), magnesium, potassium, calcium (from the bedrock) and sulphur. A series of microelements are also necessary for the nutrition of the mushrooms (iron, chlorine, boron, zinc, copper and manganese).

The purpose of this study is to identify the areas from the Subcarpathian Hills of Transylvania with high favourability for the existence and growth of the black truffle ( $T$. aestivum), using techniques of spatial analysis for the analysis of soil characteristics as a unitary entity and the integrated modelling of soil characteristics using spatial analysis for the identification of the areas favourable for $T$. aestivum.

The study area, represented by the Subcarpathian Hills from Transylvania, consists of the foothills separating the Oriental Carpathians and the Transylvania Depression, an intensely researched area due to its geomorphologic characteristics regarding its slope aspect and the symmetry of depressions (Mihăilescu, 1966; Posea, 1969; Mac, 1972).

The total surface of these hills is $5645.36 \mathrm{~km}^{2}$ out of which one notices the sector of the medium and high hills reaching $1187 \mathrm{~m}$ and the main valleys (Someșul Mare, Mureș, Târnava Mică and Târnava Mare) where the altitude reaches its minimum of $246 \mathrm{~m}$ (Fig. 1).

\section{Materials and Methods}

The implementation of the spatial analysis models relies on a solid database with an integrating capacity. The present study uses databases which differ in what concerns the format of the data: vector (soil type, soil texture, physical and chemical characteristics of soils) and raster (soil type, soil texture, $\mathrm{pH}$, gleization, stagno-gleization, hydrological soil categories) and the method of data acquisition: derivation vector-raster, spatial interpolation, integrated spatial analysis model, databases used in the spatial analysis model (Table 1).
According to the generating mode of the databases, they can be included in three major categories: primary databases (identification points from the field for $T$. aestivum), generated by acquiring $\mathrm{X}$ and $\mathrm{Y}$ coordinates using G.P.S. techniques; derived databases (generated by converting vector databases into raster databases using their specific attributes) and modelled databases (created as sub-models of the general model, usually generated by interpolating the punctual values of soil characteristics) (Table 1).

In order to finalise the database, soil maps of the study area were used together with field data as input databases for geoinformatic softwares in order to identify those physical and chemical soil characteristics which enable the development of this important natural resource ( $T$. aestivum).

The analysis of the soil characteristics which were considered for the development of the spatial analysis model was performed using integrated spatial analysis (vectorraster) and statistical principles, in order to identify the areas with different favourability degrees for $T$. aestivum, specific to each soil characteristic being analysed.

The statistical analysis used in this research is based on the identification of the minimum, maximum and average statistical indicators for each soil characteristic, as a dependent spatial database (soil type, soil texture, $\mathrm{pH}$ value, gleization, stagno-gleization) and, as an independent database of analysis, the samples for which the existence of the black truffle had been identified in the field. The analysed samples (284) were punctually localised in the field using a Magellan Explorist 210 G.P.S. For the statistical analysis, a proximity buffer of $20 \mathrm{~m}$ was considered, as a test area for the influence and probable identification of $T$. aestivum for each sample, totalising $5.86 \mathrm{~km}^{2}$.

By analysing the distribution of T. aestivum on the soil types from the sub Carpathian Hills of Transylvania one notices the rendzina soil and the brown luvic soil (podzolic) which offer good conditions of growth. Medium conditions can be found on alluvial soil, while the rest of the soil types offer only poor conditions for the growth of the black truffle, in some places even limitative ones (Table 2).
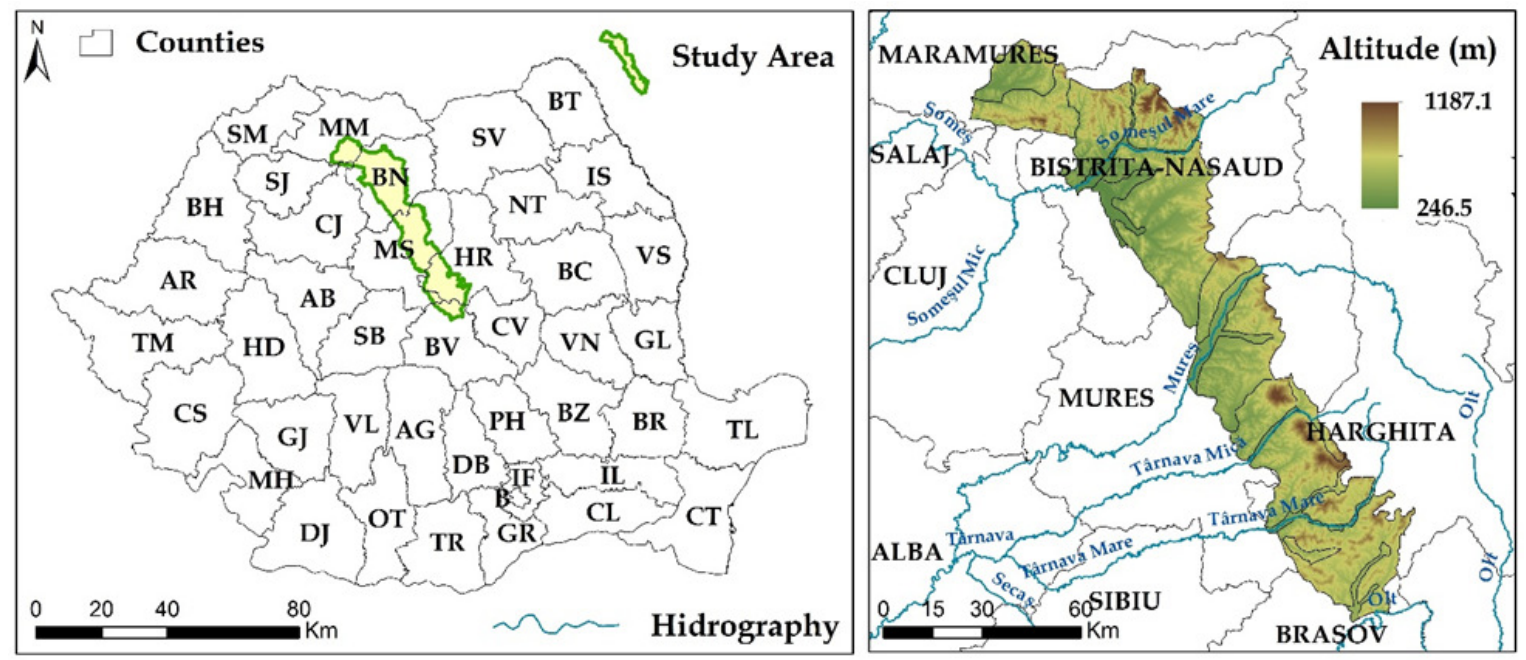

Fig. 1. Geographical position of the Subcarpathian Hills of Transylvania 
480

Tightly connected with the hydric regime of the soil, knowing the water requirement of the black truffles, the territories with high favourability were identified as the areas characterised by a varied soil texture, while the soils with clay texture were included in the medium favourability class.

By analysing the values of the soil $\mathrm{pH}$ one notices the maximum values where black truffles have been identified, ranging between 6.7 and 7.51 (Table 2). This range is considered having maximum favourability in the study area. The medium favourability is included in the interval 6.106.7 where the overlapping with the existing $T$. aestivum showed minimum values. The low favourability is determined by the value of the soil $\mathrm{pH}$ and can be spatially identified on all surfaces with values ranging between 5.46.7 and 7.51-7.66. On these surfaces the presence of the black truffle could not be statistically proven.

Regarding the stage of gleization of the soils from the Subcarpathian Hills of Transylvania, the largest surfaces where the black truffle was identified are characterised by an advanced stage of gleization with danger of water excess in the absence of artificial drainage (phreatic hydromorphic soils). The soils with a nil gleization stage (no danger of water excess) offer medium favourability for truffle development (Table 2).

Pseudo-gleization of soils must be nil in order to offer favourable conditions for the black truffle, the soils with excessive water content offering limitative conditions for the development of T. aestivum in the analysed territory.

The classification of the study area using hydrological soil categories was performed using the methodological adjustments made by Chendeș (2011) for the territory of Romania, using the hydrological soil classes from the U.S.A. in order to identify the flow potential of each soil type depending on its texture, its use and its degree of vegetation coverage. Thus, the soils from class $\mathrm{C}$ (including soils with a flow potential slightly above average, a low infiltration rate when they are completely wet, soils which hinder the downward movement of water, as well as soils with a moderately fine to fine structure) offer the best conditions for the development of $T$. aestivum.

Table 1. The database used

\begin{tabular}{|c|c|c|c|c|}
\hline & Primary Database & Used Database & Obtained Database & Database Type \\
\hline \multirow{2}{*}{1} & \multirow{2}{*}{ Soil map of Romania, 1:200000 } & Soil texture & Derived & Raster (Conversion) \\
\hline & & Soil type & Derived & Raster (Conversion) \\
\hline \multirow{3}{*}{2} & \multirow{3}{*}{$\begin{array}{l}\text { Soil Quality Monitoring in Romania, 2011, } \\
\qquad 16 \times 16 \mathrm{~km} \text {, scale 1:200000 }\end{array}$} & $\mathrm{pH}$ & Modelled (interpolation) & Raster \\
\hline & & Gleization & Modelled (interpolation) & Raster \\
\hline & & Stagno-gleization & Modelled (interpolation) & Raster \\
\hline 3 & Soil texture & \multirow{2}{*}{ Hydrological soil categories } & Modelled (Overlay) & \multirow{2}{*}{ Raster (Conversion) } \\
\hline 4 & Soil type & & Correlative and integrated analysis & \\
\hline 5 & Tuber aestivum favourability & Numeric Database & Modelled (Spatial analysis model) & $\begin{array}{c}\text { Raster } \\
\text { Final map }\end{array}$ \\
\hline 6 & Identified samples of Tuber aestivum & $\begin{array}{l}\text { Geographic position } \\
\text { Spatial extension }\end{array}$ & $\begin{array}{l}\text { Primary } \\
\text { Modelled (Buffer) }\end{array}$ & Vector \\
\hline
\end{tabular}

Table 2. Soil characteristics, statistical indicators used in the analysis and favourability classes for T. aestivum

\begin{tabular}{|c|c|c|c|c|c|c|c|}
\hline & \multirow{2}{*}{ Soil Characteristics } & \multicolumn{3}{|c|}{ Statistical Indicators } & \multicolumn{3}{|c|}{ Favourability } \\
\hline & & Minimum & Medium & Maximum & Low & Medium & High \\
\hline 1 & Soil type & Alluvial soils & Erodosoils & Rendzina & Other soil types & Alluvial soils & $\begin{array}{c}\text { Rendzina and } \\
\text { brown luvic soils } \\
\text { (podzolic) }\end{array}$ \\
\hline 2 & Soil texture & Loamy-Clayey & $\begin{array}{l}\text { Loamy-loamy- } \\
\text { clayey }\end{array}$ & Varied texture & Other textures & $\begin{array}{l}\text { Loamy- loamy- } \\
\text { clayey }\end{array}$ & Varied texture \\
\hline 3 & Soil pH & 6.10 & 6.7 & 7.51 & $\begin{array}{c}5.4-6.1 \\
7.51-7.66\end{array}$ & $6.10-6.7$ & $6.7-7.51$ \\
\hline 4 & Gleization & Nil (no danger & vater excess) & $\begin{array}{l}\text { Strong (danger of } \\
\text { water excess, if } \\
\text { there is no } \\
\text { artificial drainage) } \\
\text { (phreatic } \\
\text { hydromorphic } \\
\text { soils) }\end{array}$ & $\begin{array}{l}\text { Other classes of } \\
\text { gleization }\end{array}$ & $\begin{array}{c}\text { Nil (no danger of } \\
\text { water excess) }\end{array}$ & $\begin{array}{l}\text { Strong (danger of } \\
\text { water excess, if } \\
\text { there is no } \\
\text { artificial drainage) } \\
\text { (phreatic } \\
\text { hydromorphic } \\
\text { soils) }\end{array}$ \\
\hline 5 & Stagno-gleization & $\begin{array}{c}\text { Moderate } \\
\text { (moderate danger } \\
\text { of water excess } \\
\text { during rainy years) }\end{array}$ & $\begin{array}{l}\text { Nil (no danger } \\
\text { of water excess) }\end{array}$ & Low & $\begin{array}{l}\text { Other classes of } \\
\text { stagno-gleization }\end{array}$ & $\begin{array}{c}\text { Nil (no danger of } \\
\text { water excess) }\end{array}$ & Low \\
\hline 6 & $\begin{array}{l}\text { Hydrological soil } \\
\text { categories }\end{array}$ & $\mathrm{B}$ & $\mathrm{D}$ & $\mathrm{C}$ & $A, B$ & $\mathrm{D}$ & $\mathrm{C}$ \\
\hline
\end{tabular}


The soils from class D (soils with the highest flow potential and a very small infiltration rate when they are completely wet - represented mainly by clayey soils with a heavy texture, a large swelling potential - but also soils with a permanently high phreatic level, soils which have a clay stratum at the surface or shallow soils over an almost impermeable bedrock) offer medium conditions, while the rest of the soils from classes $\mathrm{A}$ and $\mathrm{B}$ impose specific limitatios on the development of T. aestivum.

The integration of spatial databases representing statistical indicators in a spatial analysis model for the identification of the areas with different degrees of favourability for $T$. aestivum was performed using G.I.S. spatial analysis and the integrating equation applied to the classified databases according to their specific favourability (Table 2) (Figs. 2-7).

\section{Results}

The databases representing the characteristics of the soil factors, classified by values from 1 to 3 (1- Low favourability, 2-Medium favourability, 3 - High favourability) represent the starting point for developing the model of spatial analysis used in determining the favourability of $T$. aestivum. Geoinformatic softwares allow the integration of multiple databases as singular or correlative analyses in order to highlight the manifestation of a phenomenon or process that they control. In the present study, the integration of the

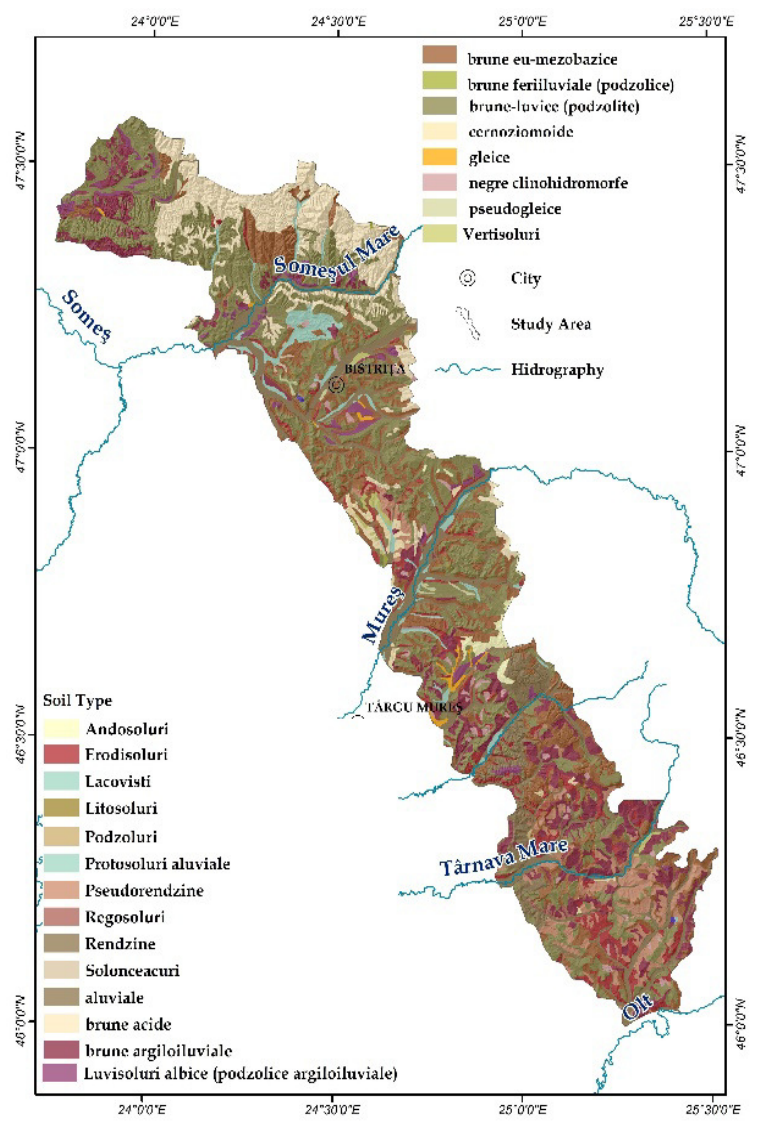

Fig. 2. Soil type from Subcarpathian Hills raster databases representing the characteristics of the soil factors (Fig. 8-13) for the identification of $T$. aestivum favourability was performed by implementing a mathematical equation of probability in a G.I.S. environment. This was materialized in a spatial analysis equation which takes into consideration the great importance of the main two factors which influence the presence of T. aestivum (hydrological soil categories and soil texture), in correlation with the rest of the factors.

The spatial analysis equation is adjusted for this study based on the model of the equation which is used in the methodology of identifying surfaces susceptible to landslides (H.G. 447/2003). The spatial analysis equation once implemented (1), the result is represented by a raster database with values between 1 and $>3$ corresponding to the three classes of final favourability (Fig. 14).

Tuber aestivum favourability $=$

soil hidrological group $*$ soil texture

4 - soll type + gleization + stagnogleization $+p H)$

Thus, by analysing the final results which were classified using the initial favourability classes (values between 1-2 low favourability, 2-3 - medium favourability, $>3$ and $<4-$ high favourability) one notices the spatial extension of the first class (low favourability) both in the whole study area and at the level of landform units, without being able to correlate this with either the hydrography or the vegetation from the area.

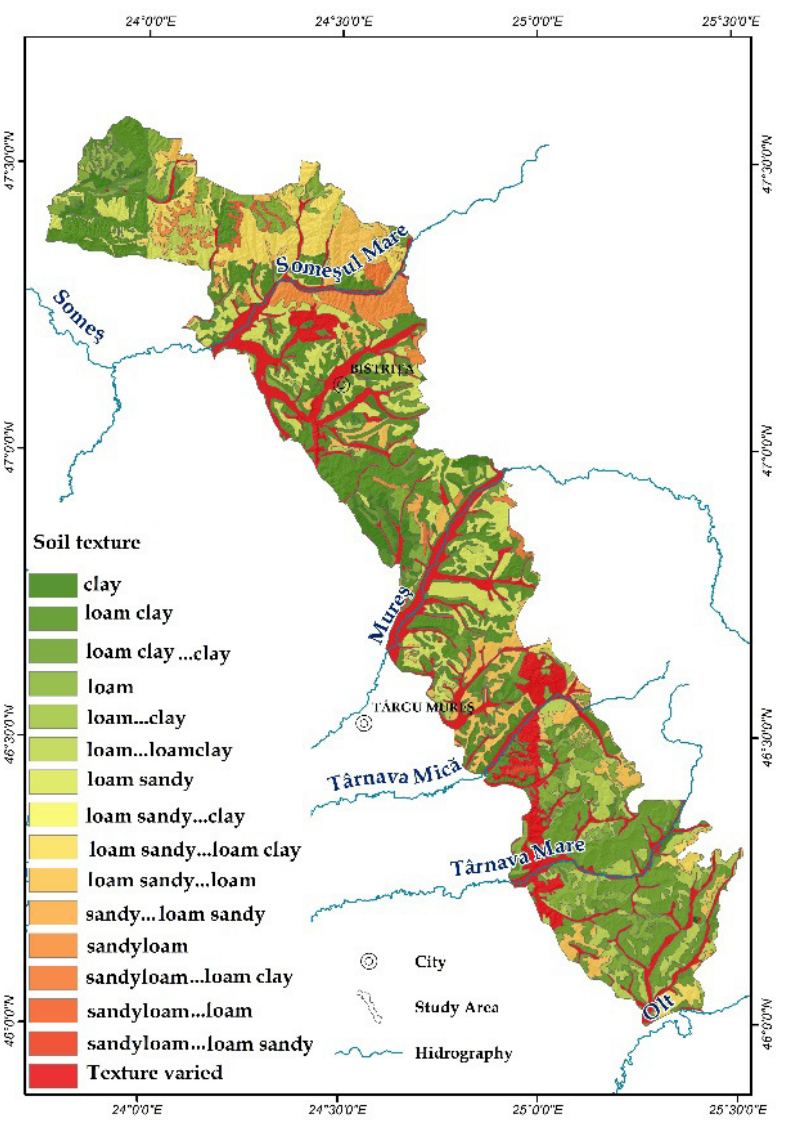

Fig. 3. Soil texture from Subcarpathian Hills 
482

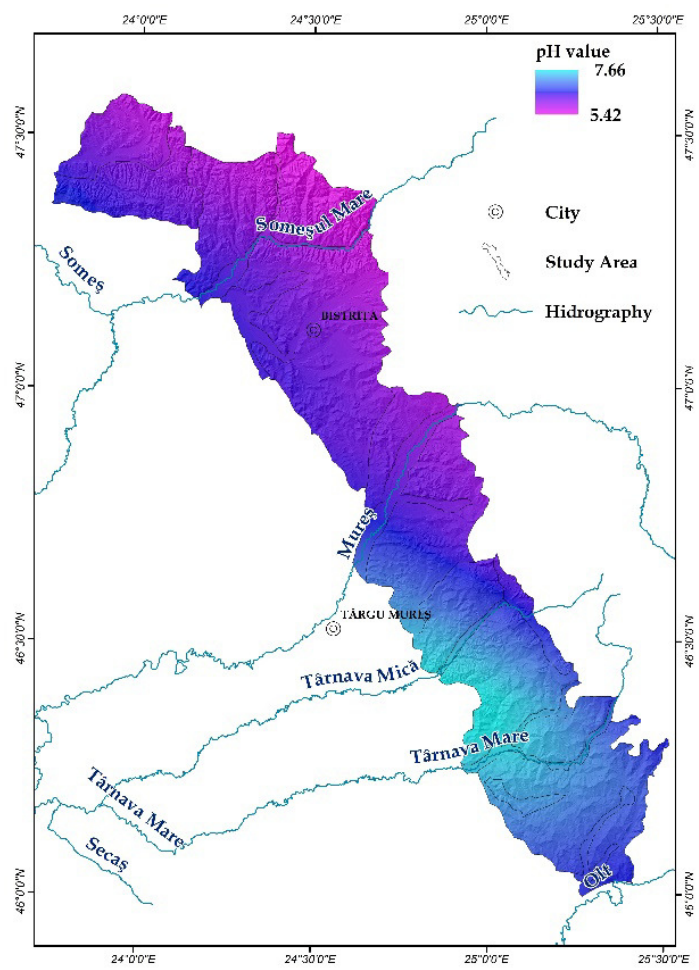

Fig. 4. Variation of $\mathrm{pH}$ from Subcarpathian Hills

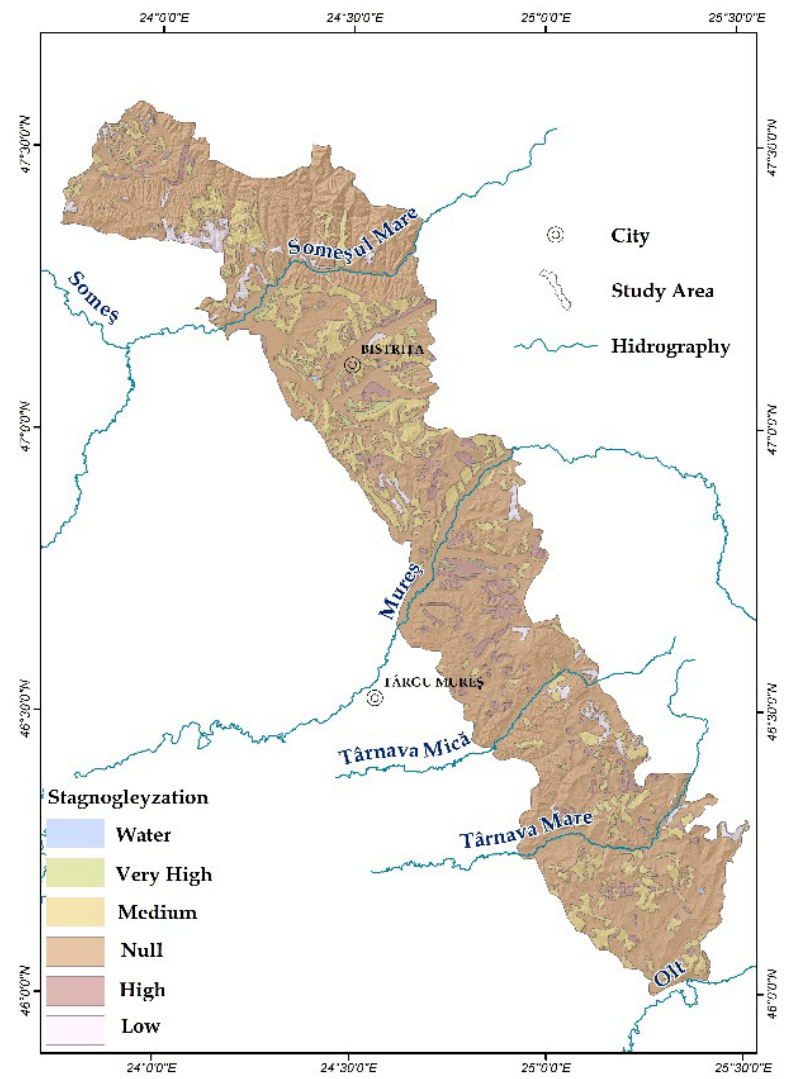

Fig. 6. Intensity of stagnogleization from Subcarpathian Hills

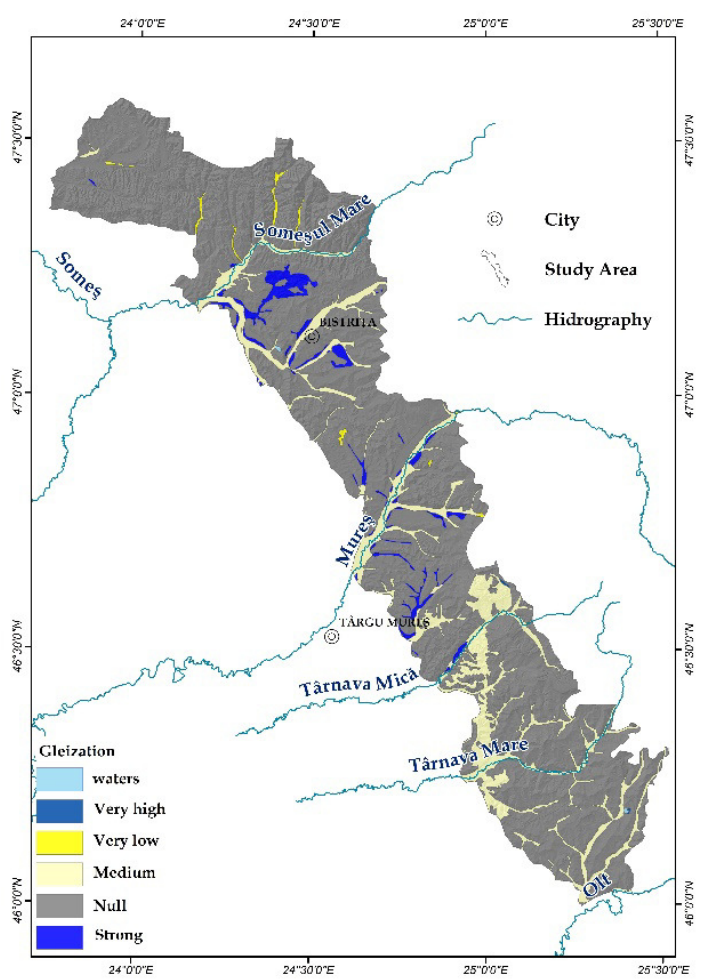

Fig. 5. Intensity of gleization from Subcarpathian Hills

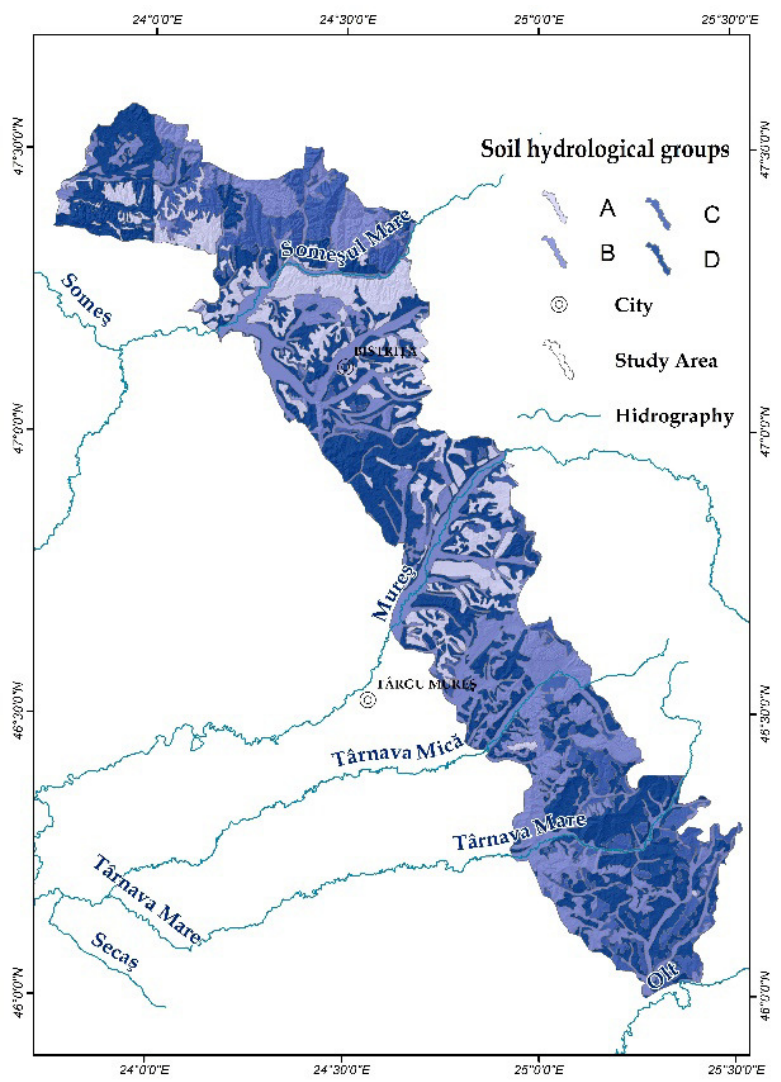

Fig. 7. Soil hydrological groups from Subcarpathian Hills 


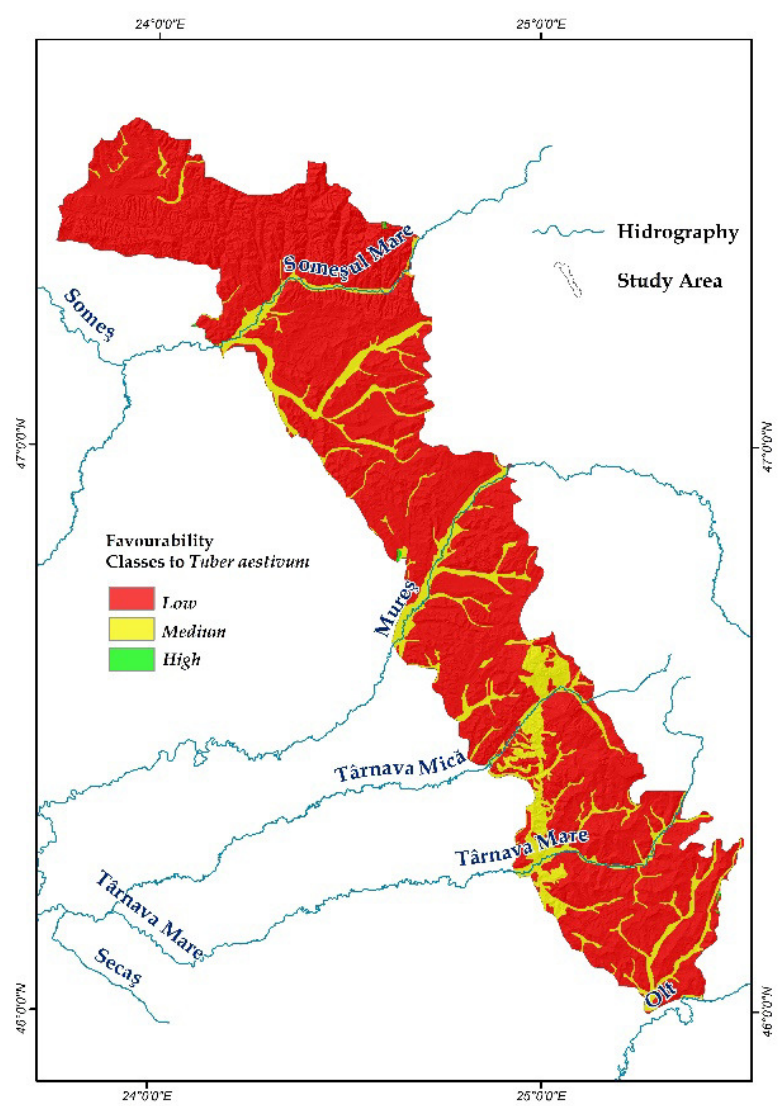

Fig. 8. Favourability classes according to soil type

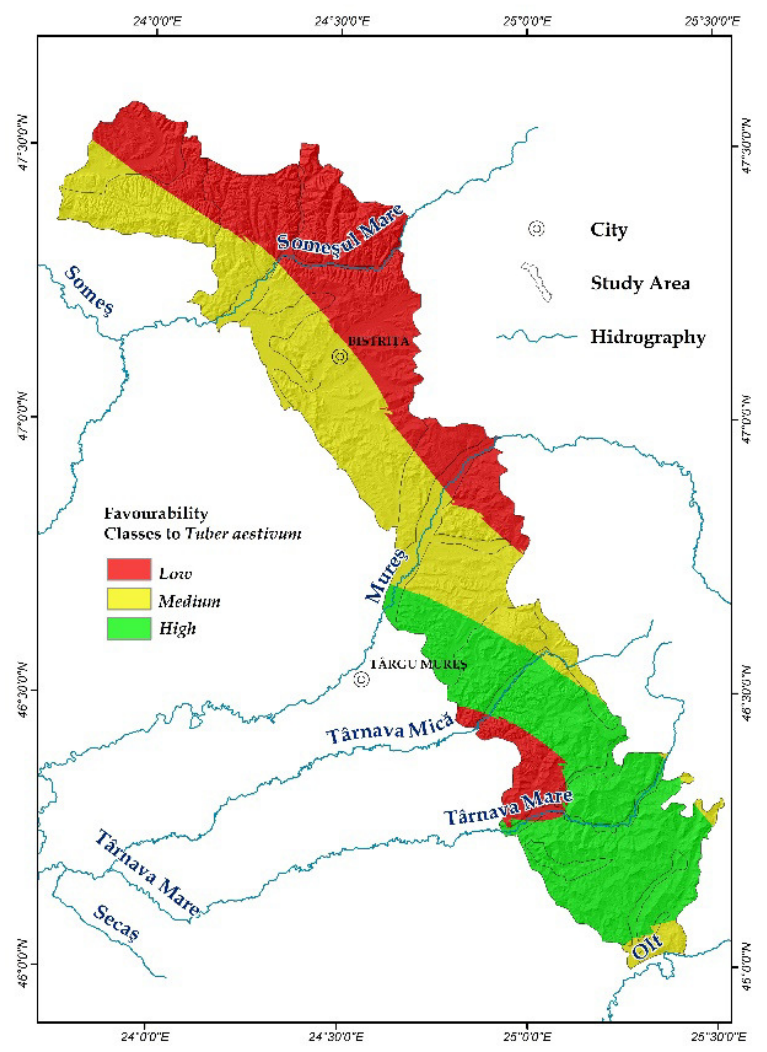

Fig. 10. Favourability classes according to the values of $\mathrm{pH}$

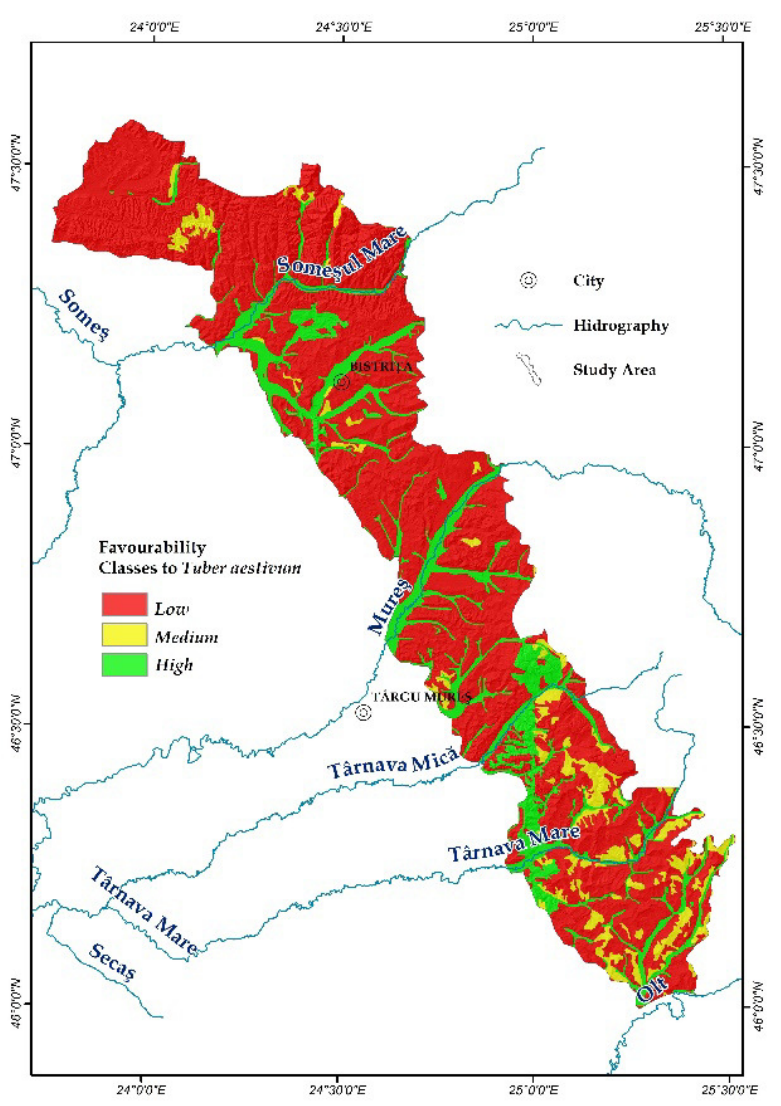

Fig. 9. Favourability classes according to soil texture

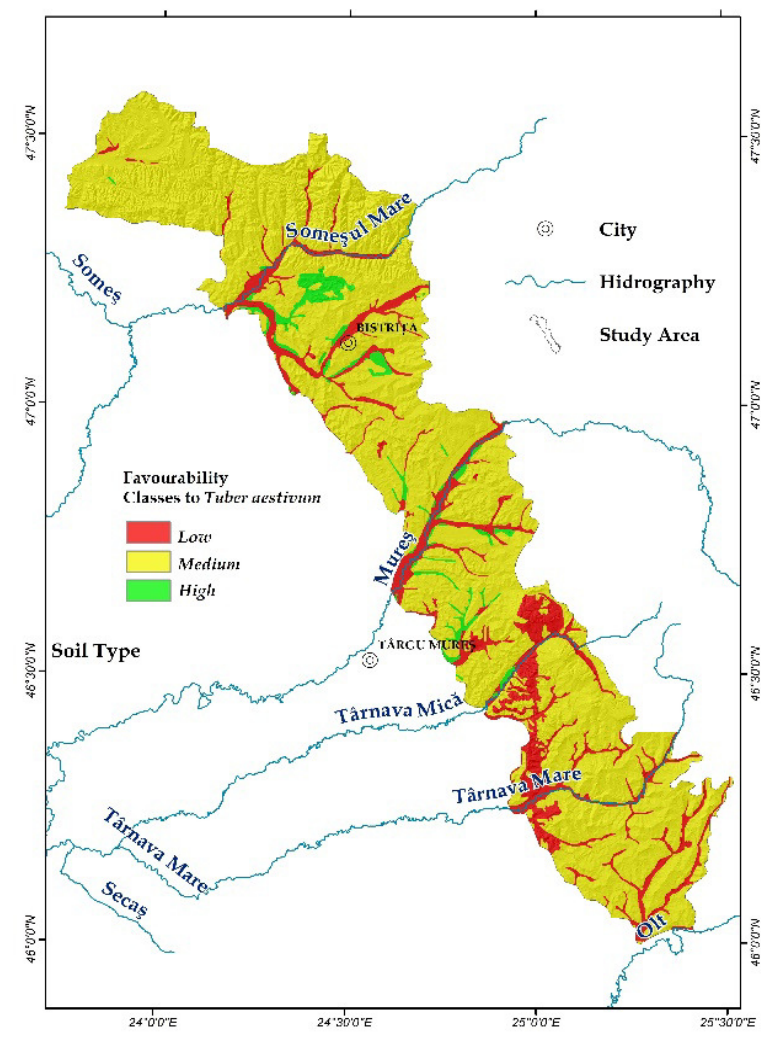

Fig. 11. Favourability classes according to the intensity of gleization 
484

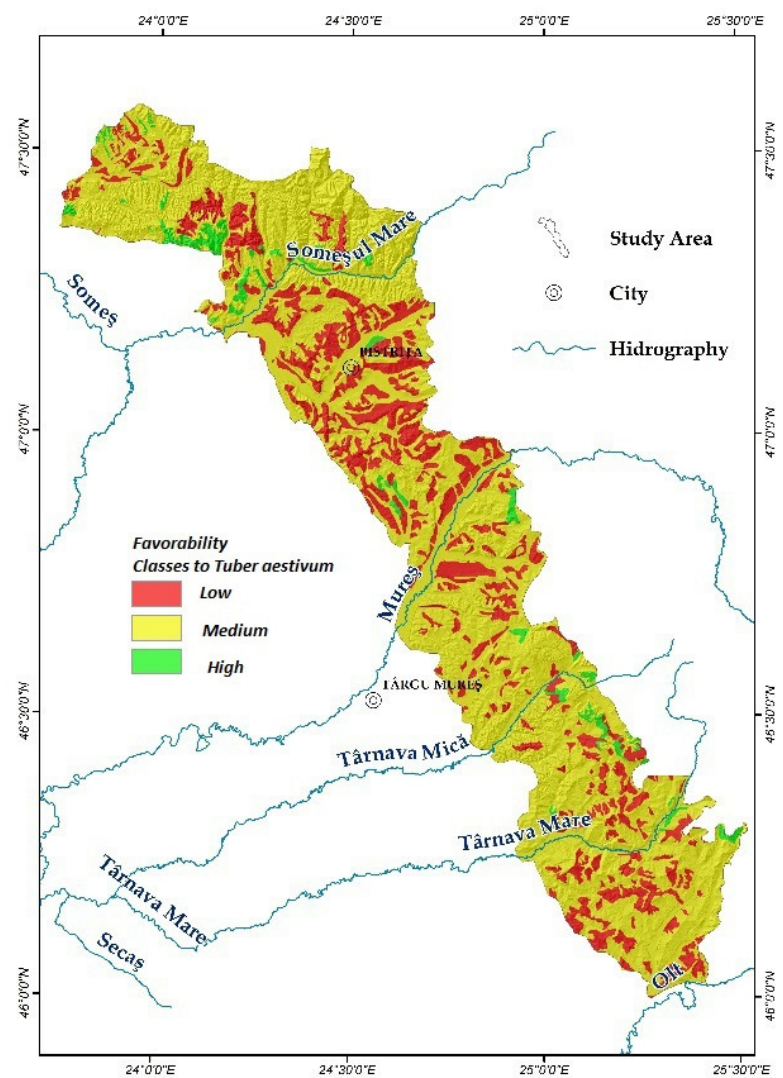

Fig. 12. Favourability classes according to the intensity of stagnogleization

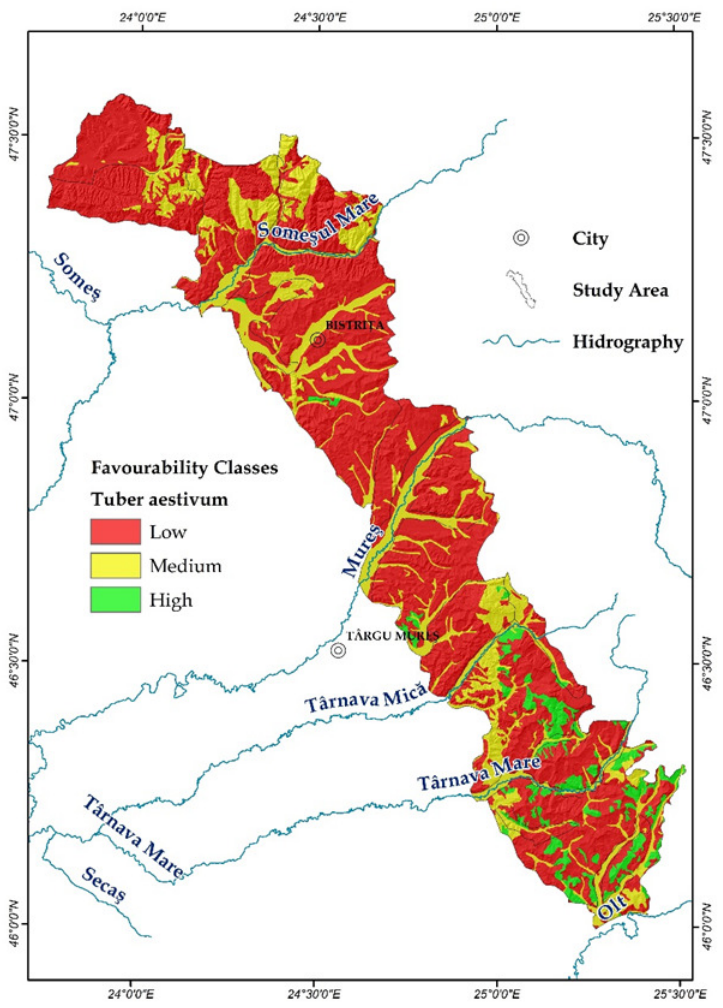

Fig. 14. Favourability class map for Tuber aestivum

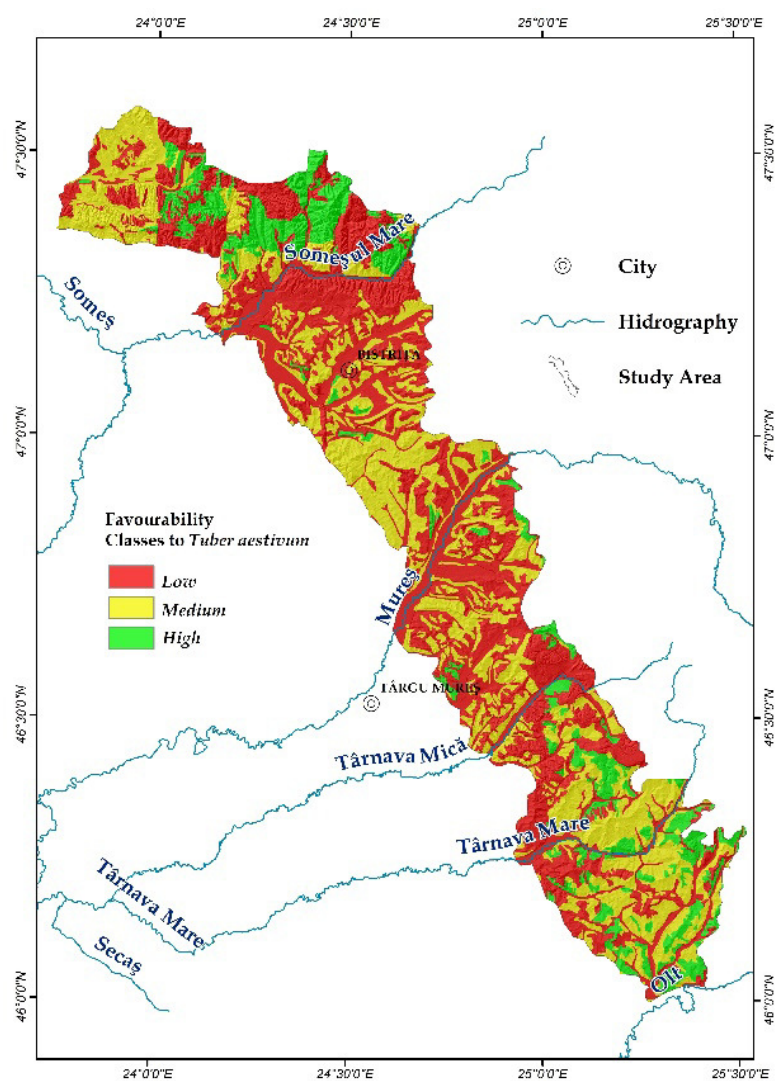

Fig. 13. Favourability classes according to the hydrological soil classes

The other two classes, medium and high, have a reduced spatial extension and can usually be identified on the main valleys (medium class), on the hills with gentle slopes and in the vicinity of tree groves (high class).

The quantitative analysis of the final results highlight the same spatial distribution of the favourable surfaces, the low favourability class dominating the territory with a percentage of $69.37 \%$ of the total study area.

The classes of medium and high probability represent approximately $30 \%$ of the entire study area, the medium class having a larger percentage $(25.45 \%)$ than the high favourability class $(5.18 \%)$, both in their comparative analysis and in reference to the whole study area (Table 3 ).

Related to the major landforms included in the Subcarpathian Hills of Transylvania, one notices the Homoroade Subcarpathians and the Târnave Hills as having high favourability for the development of $T$. aestivum. By applying the spatial analysis model, on the first landform unit the favourable area has $154.18 \mathrm{~km}^{2}$ and on the second one, $100.9 \mathrm{~km}^{2}$. The quantitative analysis indicates the fact that the landform units below $500 \mathrm{~m}$ have a relatively high favourability for the identification of $T$. aestivum, in this case, Mureș Hills and the Subcarpathian depressions at the contact with high hills. 
Table 3. Classification of landform sub-units from the Subcarpathian Hills of Transylvania using Tuber aestivum favourability classes

\begin{tabular}{|c|c|c|c|c|}
\hline & \multirow{2}{*}{ Landform sub-units } & \multicolumn{3}{|c|}{ Favourability Classes } \\
\hline & & Low & Medium & High \\
\hline 1 & Muscelele Năsăudului & 470.54 & 262.02 & 0.00 \\
\hline 2 & Breaza Hill & 285.46 & 70.55 & 0.00 \\
\hline 3 & Lăpuș Depression & 252.62 & 22.68 & 0.00 \\
\hline 4 & Subcarpathian Depressions & 94.92 & 134.17 & 8.17 \\
\hline 5 & Mureș Hill & 674.46 & 108.97 & 12.07 \\
\hline 6 & Tîrnave Hills & 629.91 & 215.1 & 100,9 \\
\hline 7 & Sovata-Praid Depression & 45.97 & 35.21 & 2.32 \\
\hline 8 & Homoroade Subcarpathians & 444.39 & 138.91 & 154.18 \\
\hline 9 & Bistrița Depression & 894.66 & 192.68 & 6.16 \\
\hline 10 & Târnava Mică Valley & 3.60 & 23.00 & 0.00 \\
\hline 11 & Someșul Mic and Someșul Mare Valleys & 21.19 & 63.62 & 0.00 \\
\hline 12 & Tîrnava Mare Valley & 24.46 & 56.62 & 8.79 \\
\hline 13 & Mureş Valley & 72.55 & 112.72 & 0.00 \\
\hline & Total $\left(\mathrm{km}^{2}\right)$ & 3914.73 & 1436.25 & 292.58 \\
\hline & Total (\%) & 69.37 & 25.45 & 5.18 \\
\hline
\end{tabular}

Fig. 15. Model validation (Google Maps, 2017)

\section{Conclusions}

The soil factor represents one of the main components which influence the spatial development of Tuber aestivum. The analysis of soil characteristics in direct correlation with the statistical samples identified in the field, based on the statistical elements which were calculated as a result of the correlation, determines the successful identification of areas with different degrees of favourability.

The integrated analysis in a G.I.S. environment brings an important benefit for the correlation process and the quantitative analysis of the final results, as well as for their presentation and dissemination.

Together with these intrinsic soil characteristics, the study of truffle distribution in Romania also uses the influence of the flow of precipitation water, the influence of annual average precipitation amount, as well as the tree species associated with its development. There is a reciprocal connection between trees and truffles as the tree offers the nutrients necessary for the development of the mushroom, like carbohydrates and vitamins, and the mushroom gives the tree important mineral substances.

The validation of the results was based on the comparison of the extent of the high favourability class with the field using Google Earth images as a mapping underlay. A random area was selected for the validation stage and its correspondence with forested surfaces was observed, as $T$. aestivum develops symbiotically with tree species belonging to the Quercus genus (Fig. 15). The comparative analysis of the overlapping areas from the high favourability class and the areas with deciduous forests (dominantly Quercus) highlights the good validation of the results obtained through spatial analysis. There is a $94 \%$ overlapping, indicating the applicability of the model in identifying the favourability of T. aestivum.

In order to additionally evaluate the validation degree of the model, a second validation method was used, hunting for $T$. aestivum on the surfaces included in the high favourability class. 15 areas were randomly selected from the maximum favourability class where a specialised truffle seeker using dogs of the Lagoto Romaniov breed managed to identify and pick $T$. aestivum from 12 test surfaces. This result further highlights and proves the great degree of model validity and recommends its usage in other specialised studies using the presented methodology.

The generation of the databases, their quality and the rigorous development of the spatial analysis model from the present study has led to very good results which were successfully validated in the field. Therefore, we support the use of this model for areas with similar soil and landscape characteristics. 
486

\section{Authors Contribution}

All authors have contributed equally to the work.

\section{References}

Benucci GMN, Bonito G, Baciarelli LF, Bencivenga M (2012). Mycorrhization of Pecan trees (Carya illinoinensis) with commercial truffle species: Tuber aestivum Vittad. and Tuber borchii Vittad. Mycorrhiza 22(5):383-392.

Ceruti A, Fontana A, Nosenzo C (2003). Le specie europee del genere Tuber. Una revisione storica. Museo Regionale di Scienze Naturale, Torino 467.

Chendeș V (2011). Resursele de apă din Subcarpații de la Curbură. Evaluări geospațiale. Ed. Academiei Române, București.

Chevalier G (2009). The truffle of Europe (Tuber aestivum Vitt.): ecology and possibility of cultivation. In: Centre of Biodiversity (Ed). First Conference on the European Truffle Tuber aestivum/uncinatum. University of Vienna, Vienna, Austria.

Csorbainé AG (2011). Studies on cultivation possibilities of summer truffle (Tuber aestivum Vittad.) and smooth black truffle (Tubermacrosporum Vittad.) in Hungary. Phd Thesis, Szent István University.

Dam SM, Trinh XN, Vo Trung A, Hoffmann S, Szeglet P (2012). Compare the effect of Terfezia and Tuber aestivum on Pinus caribaea development in Vietnam. In: 3rd International Conference on Biology, Environment and Chemistry IPCBEE 46:62-66.

Deveau A, Palin B, Delaruelle C, Peter M, Kohler A, Pierrat JC, Sarniguet A, Garbaye J, Martin F, Frey-Klett P (2007). The mycorrhiza helper Pseudomonas fluorescens BBc6R8 has a specific priming effect on the growth, morphology and gene expression of the ectomycorrhizal fungus Laccaria bicolor S238N. New Phytologist 175(4):743-755.

Garcia-Montero L, Moreno D, Monleon V, Arredondo-Ruiz F (2014). Natural production of Tuber aestivum in central Spain:Pinus spp. versus Quercus spp. Brûles. Forest Systems 23(2):394-399.

Gryndler M, Černá L, Bukovská P, Hršelová H, Jansa J (2014). Tuber aestivum association with non-host roots. Mycorrhiza 24(8):603-610.

Gryndler M, Hršelová H (2012). Isolation of bacteria from ectomycorrhizae of Tuber aestivum Vittad. Acta Mycologica 47(2):155-160.

Harley JL, Smith SE (1983). Mycorrhizal symbiosis. Academic Press, London.
Linderman RG (1988). Mycorrhizal interactions with the rhizosphere microflora: the mycorrhizosphere effect. Phytopathology 78(3):366371.

Mac I (1972). Subcarpaţii Transilvaniei dintre Mureş şi Olt: studiu geomorphologic [Subcarpathians of Transylvania between Mureş and Olt: geomorphologic study].Editura Academiei, București.

Mihăilescu V (1966). J'etat actual de nos connaissances sur le relief des Carpathes roumaines pendant le Quaternaire. Geographica Polonica, Geomorphological Problems of the Carpathians II 10:9-36.

Milenković M, Glamocija J, Velijović V, Vukojević J (1992). Record of two Tuber (T. aestivum and T. melanosporum) species in Serbia. Achieves of Biological Sciences 44:223-228.

Montecchi A, Sarasini M (2000). Funghi ipogei d'Europa. Associazione Micologica Bresadola (Eds). Fondazione Centro Studi Micologici, Trento.

Pacioni G, Pomponl G (1991). Genotypic patterns of some Italian populations of the Tuber aestivum - T. mesentericum complex. Mycotaxon 42:171-179.

Posea GR (1969). Asupra suprafețelor şi nivelelor morfologice din sud-vestul Transilvaniei [On the surfaces and the morphological levels in the southwest of Transylvania]. Lucrările Ştiințifice ale Institutului Pedagogic din Oradea.

Stobbe U, Egli S, Tegel W, Peter M, Sproll L, Büntgen U (2013). Potential and limitations of Burgundy truffle cultivation. Applied Microbiology and Biotechnology 97(12):5215-5224.

StreiblováE, GryndlerováH, ValdaS, Gryndler M(2010). Tuber aestivum hypogeous fungus neglected in the Czech Republic: a review. Czech Mycology 61(2):163-173.

Wang G, Li Y, Li D, Tang Y (2008). Determination of 5 alphaandrost-16en-3 alpha-ol in truffle fermentation broth by solid-phase extraction coupled with gas chromatographyflame ionization detector/electron impact mass spectrometry. Journal of Chromatography B-Analytical Technologies in the Biomedical and Life Sciences 870(2):209-215.

Wedén C, Pettersson L, Danell E (2009). Truffle cultivation in Sweden: Results from Quercus robur and Corylus avellana field trials on the island ofGotland. Scandinavian Journal of Forest Research 24(1):37-53.

Zambonelli A, Iotti M, Piattoni F (2012). Chinese Tuber aestivum sensu lato in Europe. The Open Mycology Journal 6:22-26.

Zoltán B, MerenyiZ, IIlyes Z, Laszlo P, Attila A, Papp L, ... Brandt S(2009). Studies on ecophysiology of Tuber aestivum populations in CarpathoPannonian region. Acta Mycologica 47(2):221-226. 